\title{
Article \\ Food-Borne Nanocarriers for Calcium Delivery: A New Choice for Nutrient Supplements
}

\author{
Nanying Wang ${ }^{1,2,3}$, Yannan Chen ${ }^{1,2,3}$, Yukun Song ${ }^{1,2,3}$, Deyang $\mathrm{Yu}^{1,2,3}$ and Mingqian Tan $1,2,3, *$ (1) \\ 1 Academy of Food Interdisciplinary Science, School of Food Science and Technology, Dalian Polytechnic \\ University, Qinggongyuan1, Gangjingzi District, Dalian 116034, China; louis493942754@gmail.com (N.W.); \\ 18954530681@163.com (Y.C.); songyukun@126.com (Y.S.); yudy0411@163.com (D.Y.) \\ 2 National Engineering Research Center of Seafood, Dalian Polytechnic University, Dalian 116034, China \\ 3 Collaborative Innovation Center of Seafood Deep Processing, Dalian Polytechnic University, \\ Dalian 116034, China \\ * Correspondence: mqtan@dlpu.edu.cn; Tel.: +86-0411-86318657
}

check for updates

Citation: Wang, N.; Chen, Y.; Song, Y.; Yu, D.; Tan, M. Food-Borne

Nanocarriers for Calcium Delivery: A New Choice for Nutrient

Supplements. Foods 2022, 11, 308.

https://doi.org/10.3390/

foods11030308

Academic Editors: Wojciech

Kolanowski and Anna

Gramza-Michałowska

Received: 18 December 2021

Accepted: 20 January 2022

Published: 24 January 2022

Publisher's Note: MDPI stays neutral with regard to jurisdictional claims in published maps and institutional affiliations.

Copyright: (C) 2022 by the authors. Licensee MDPI, Basel, Switzerland. This article is an open access article distributed under the terms and conditions of the Creative Commons Attribution (CC BY) license (https:// creativecommons.org/licenses/by/ $4.0 /)$.

\begin{abstract}
Calcium is considered as an important nutrient element for the maintenance of human health, and food-borne nanoparticles (FNs) produced during food processing may have potential as nanocarriers for calcium ion delivery. Beef is an important source of animal protein that has high protein and low fat content and is rich in a variety of amino acids; thus, beef may be a suitable material for the development of calcium nanocarriers. In this paper, FNs were synthesized from beef by one-step hydrothermal synthesis. The FNs had a spherical shape with a size of about $3.0 \mathrm{~nm}$ and emitted a bright blue fluorescence under $365 \mathrm{~nm}$ ultraviolet irradiation. The amino nitrogen atom and carboxyl oxygen atom of the functional groups on the surface of the FNs were the main binding sites for the chelation of $\mathrm{Ca}$ (II). The size of the FNs-Ca(II) complex was about $4.75 \mathrm{~nm}$, and the specific signal peak of calcium at $3.7 \mathrm{keV}$ was observed in its energy dispersive X-ray spectroscopy spectrum. The viability of cells treated with FNs-Ca(II) was more than $65 \%$, while viability was only $60 \%$ after treatment with $\mathrm{CaCl}_{2}$. The results showed that the $\mathrm{FNs}$ from beef have great potential in calcium delivery for the development of a calcium supplement.
\end{abstract}

Keywords: beef; one-step hydrothermal; food-borne nanoparticles; calcium binding; nutrient supplements

\section{Introduction}

Calcium has been regarded as an essential nutrient element in life [1]; it has many roles in metabolism and life maintenance and is closely related to several functions, such as immunity, nerve transmission, digestion, and circulation [2]. Many physiological diseases, such as bone and tooth dysplasia in children [3], cramps and pregnancy hypertension syndrome in women $[4,5]$, and osteoporosis and fracture in the elderly, are caused by a lack of calcium $[6,7]$. Therefore, the health problems caused by calcium deficiency should arouse enough attention to promote the essential development of innovative calcium supplements to overcome calcium deficiency diseases.

Inorganic calcium salts, such as calcium carbonate, are the most common calcium supplement because of their high calcium content [8]. However, in the absorption process, a large amount of gastric acid will be consumed [9], resulting in an increased risk of kidney stones [10]. Fructooligosaccharides can provide calcium with better water solubility, less intestinal stimulation, and higher bioavailability; however, the calcium content is significantly lower than that in inorganic calcium salt [11]. In recent years, peptides from food-grade protein that can chelate calcium ions have been developed as new calcium supplements. For instance, Mellander et al. hydrolysed milk with trypsin and isolated casein phosphopeptides (CPPS) with calcium-chelating ability [12]. Zhao et al. reported on a peptide in the hydrolysate of Pacific cod skins with a calcium-binding ability [13]. Sun et al. described a heptapeptide from the ovum of sea cucumber as a chelating agent for 
enhanced calcium delivery [14]. Although these peptides have excellent calcium chelating abilities, the process of preparing the peptides is tedious and costly, which makes it difficult to be widely used [15]. Therefore, the development of an innovative calcium carrier with a simple production process, higher stability, and better biocompatibility is highly desirable. In recent years, food-borne nanoparticles (FNs) from our daily foods have attracted wide attention due to their advantages, including their low cost, easy attainability, good water solubility, excellent optical performance, and good biocompatibility [16-19]. Zhou et al. found monodisperse high fluorescence FNs with a size of about $3 \mathrm{~nm}$ by the hydrothermal treatment of milk, which is a product consumed in daily life [20]. Song et al. reported nanoparticles extracted from roast sturgeon that could be used as nanocarriers for Fe(II) delivery [21]. Geng et al. reported that water-soluble FNs derived from beef broth treated by a pressure-cooker for $70 \mathrm{~min}$ have a potential application as nanocarriers for zinc [22]. It can be seen that FNs are ubiquitous in daily foods, and they have abundant functional groups on their surface, high water solubility, and an ultra-small size. Therefore, it is reasonable to assume that it may be an innovative idea to use FNs as a calcium carrier.

Herein, the FNs from beef were prepared by the hydrothermal treatment of beef, and the formation of FNs-Ca(II) complexes were fully characterized. Beef was selected as the raw material for the preparation of calcium nanocarriers because of its high protein content, low fat level, and rich variety of amino acids that are easily available in animal protein. The binding sites were analysed using spectrographic techniques. Finally, the cytotoxicity and biodistribution of FNs-Ca(II) was examined in Caco-2 cells using FNs as a control. Our data indicate that FNs with multifunctional groups have the potential to be used as carriers for calcium delivery.

\section{Materials and Methods}

\subsection{Materials}

Beef (short plate) was procured from the Qianhe market of agricultural products in Dalian, China. Anhydrous calcium chloride, potassium bromide, and other chemicals in this study were supplied by local reagent vendors. The Annexin V FITC/PI staining apoptosis kit was bought from Nanjing Jiancheng Bioengineering Institute.

\subsection{Synthesis and Purification of FNs}

At first, the beef $(5 \mathrm{~g})$ was crushed into paste by a meat grinder. The paste and deionized water $(15 \mathrm{~mL})$ were added to a $20 \mathrm{~mL}$ Teflon-lined autoclave which was then treated in an oven at $180{ }^{\circ} \mathrm{C}$ for $4 \mathrm{~h}$. The suspension was poured out, centrifuged at $8000 \mathrm{rpm}$ for $10 \mathrm{~min}$, and the yellow filtrate was collected. Subsequently, the same volume of ethyl acetate was added to extract five times to remove the hydrophobic constituents. The fluorescent fractions were then collected by a Sephadex G-25 column with deionized water as an eluent. After they were concentrated and lyophilized, the FNs were finally obtained and stored at $-80^{\circ} \mathrm{C}$ for later use.

\subsection{Preparation of the FNs-Ca(II) Complex}

A total of $0.5 \mathrm{~g}$ of FNs were dispersed in $10 \mathrm{~mL}$ of sodium phosphate buffer $(20 \mathrm{mM})$ at $\mathrm{pH} 7.8$, heated in a water bath at $50^{\circ} \mathrm{C}$ for $5 \mathrm{~min}$, and then $1.5 \mathrm{~g}$ of $\mathrm{CaCl}_{2}$ were added. The FNs-Ca(II) complex was formed at $50{ }^{\circ} \mathrm{C}$ for $30 \mathrm{~min}$ under magnetic stirring. Thereafter, ultrafiltration (3000 Da) was used to centrifuge the $\mathrm{FNs}-\mathrm{Ca}$ (II) complex at $4{ }^{\circ} \mathrm{C}$, with a speed of $8000 \mathrm{rpm}$ for $10 \mathrm{~min}$. The supernatant was collected using a molecular weight cut-off of 3000 Da to remove the unbound calcium ions. After lyophilization, the FNs-Ca(II) complex was collected as a white powder.

\subsection{FN and FNs-Ca(II) Complex Analysis}

The shape and size of the prepared FNs and FNs-Ca(II) were characterized by transmission electron microscopy (TEM) using a JEM-2100 from JEOL Ltd. (Tokyo, Japan). A Lambda 35 spectrophotometer (PerkinElmer, Waltham, MA, USA) was used for the 
analysis of the ultraviolet-visible (UV-Vis) spectra of FNs and FNs-Ca(II). Fluorescence spectra were analysed by a F-2700 fluorescence spectrometer (Hitachi, Tokyo, Japan). An FLS 980-spectrofluorometer from Edinburgh Instruments (Edinburgh, UK) was used to measure lifetime with a $320 \mathrm{~nm}$ laser as the excitation source. X-ray diffraction (XRD), X-ray photoelectron spectroscopy (XPS), Fourier transform infrared spectroscopy (FT-IR), and zeta potential analysis were conducted using previously reported methods [15]. The microstructure and local element composition of the FNs and FNs-Ca(II) were characterized by a JSM-7800F scanning electron microscope from JEOL Ltd. (Tokyo, Japan). The ${ }^{1} \mathrm{H}$ NMR spectra were obtained using a Bruker AV-400 analyser (Daltonics, Germany) with dimethyl- $\mathrm{d}_{6}$ sulfoxide as the solvent.

\subsection{Calcium-Binding Capacity Assay}

FNs were dispersed in deionized water at a concentration of $3 \mathrm{mg} \mathrm{mL}^{-1}$ and different masses of $\mathrm{CaCl}_{2}$ were added to the solution to achieve the mass ratios of $\mathrm{CaCl}_{2}$ to $\mathrm{FNs}_{\text {s }}$ 1:3, 1:2, 1:1, 2:1 and 3:1. All testing samples were continuously stirred at $50{ }^{\circ} \mathrm{C}$ for $30 \mathrm{~min}$, and then transferred to a dialysis bag (500 Da) to remove free calcium for $48 \mathrm{~h}$. Finally, the volume of all samples was adjusted to $3 \mathrm{~mL}$ and the binding capacity of the FNs for calcium at different mass ratios was measured by flame atomic absorption spectrometry (Hitachi, Kyoto, Japan).

\subsection{Cytotoxicity and Biodistribution Analysis of FNs-Ca(II) in Caco-2 Cells}

The Caco-2 cells bought from the Shanghai Institute of Biological Sciences, Chinese Academy of Sciences (Shanghai, China) were cultured in an MEM medium containing $1 \%$ penicillin-streptomycin and $20 \%$ fetal bovine serum and incubated at $37{ }^{\circ} \mathrm{C}$ in a $5 \% \mathrm{CO}_{2}$ humidified atmosphere. The potential toxicity of the $\mathrm{FNs}, \mathrm{FNs}-\mathrm{Ca}(\mathrm{II})$, and $\mathrm{CaCl}_{2}$ to $\mathrm{Caco}-2$ cells was detected using an MTT assay [16]. First, the Caco-2 cells were added into 96-well plates at a density of $1 \times 10^{5}$ cells per well and incubated for $24 \mathrm{~h}$. After removal of the medium, $100 \mu \mathrm{L}$ of the samples with different concentrations $(0.5,1.0,1.5,2.0,2.5$, and $3.0 \mathrm{mg} \mathrm{mL}^{-1}$ ) were added and cultured for another $24 \mathrm{~h}$. Then, $20 \mu \mathrm{L}$ of MTT at a final concentration of $2.5 \mathrm{mg} \mathrm{mL}^{-1}$ was added into each well for $4 \mathrm{~h}$ at $37^{\circ} \mathrm{C}$. Later, the supernatant was carefully removed and $100 \mu \mathrm{L}$ of dimethylsulfoxide solution was added. The cell viability was evaluated by measuring the absorbance at $570 \mathrm{~nm}$. Annexin V-FITC/PI staining in a flow cytometer from BD (Franklin Lakes, NJ, USA) was used to measure the apoptosis and necrosis of Caco- 2 cells. The distribution of FNs-Ca(II) $\left(1 \mathrm{mg} \mathrm{mL}{ }^{-1}\right)$ was determined by a confocal laser fluorescence microscope (SP8 model, Leica, Wetzlar, Germany).

\section{Results and Discussion}

\subsection{TEM Analysis of FNs-Ca(II)}

The FNs synthesized from beef using a one-step hydrothermal synthesis method at $180{ }^{\circ} \mathrm{C}$ for $4 \mathrm{~h}$ were used as nanocarriers for $\mathrm{Ca}$ (II) (Figure 1a). As shown in Figure 1, the TEM images indicated that the FNs and FNs-Ca(II) were nearly spherical and uniformly dispersed (Figure 1b,c). The size distribution range of the beef FNs was about $3.0 \mathrm{~nm}$, based on the calculations of a random selection of 100 particles (Figure 1d). Under high temperature and pressure, the proteins, lipids, and other substances in beef were broken down and condensed into small size FNs [23]. On the other hand, the size distribution range of FNs-Ca(II) was 3.0-7.0 nm, with an average size of $4.75 \mathrm{~nm}$ (Figure 1e). The size of FNs-Ca(II) was significantly larger than that of the FNs. The reason was possibly due to the interaction between the FNs and calcium after the FNs had chelated Ca(II). Similar results were also found in our previous studies [15]. In addition, the aqueous solutions of the FNs and FNs-Ca(II) were colourless and transparent; however, they exhibited blue fluorescence (Figure 1b,c, inset) under the illumination of a $365 \mathrm{~nm}$ ultraviolet light, which was consistent with the FNs from other foods [18]. The calcium-binding capacity of the FNs measured by flame atomic absorption spectrometry (Figure S1a) showed that with 
the increase in the proportion of calcium ions, the calcium-binding capacity also increased. When the mass ratio of calcium to FNs was $3: 1$, the binding ability was 3.5 times than that of the 1:3 ratio. This indicated that there were multiple binding sites on the surface of the FNs for calcium ions. Therefore, the mass ratio of 3:1 for calcium to FNs was selected and tested in the following experiments.

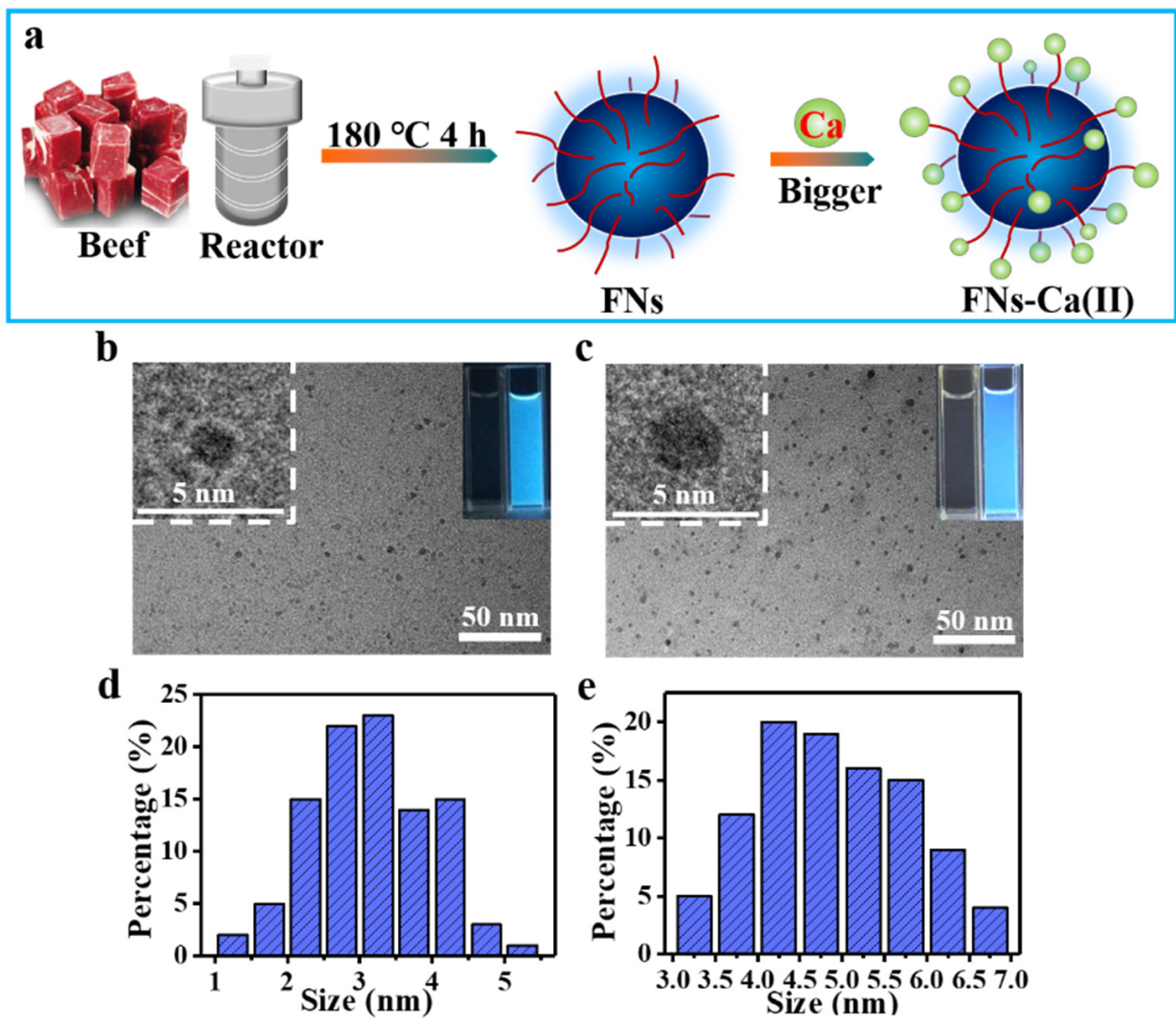

Figure 1. (a) Schematic illustration showing the beef FNs binding with calcium ions (FNs-Ca(II)). TEM images of FNs (b) and the FNs-Ca(II) complexes (c); insets represent high-resolution TEM images and the fluorescent photographs of water (left) and FNs/FNs-Ca(II) (right) under a UV lamp. Size distribution histogram for FNs (d) and FNs-Ca(II) (e).

\subsection{Optical Property Analysis of FNs and FNs-Ca(II)}

The optical property analysis showed that the FNs and FNs-Ca(II) complexes exhibited excitation-dependent fluorescence emissions, which were located at $415 \mathrm{~nm}$ and $421 \mathrm{~nm}$, respectively (Figure 2a,b). The emission peaks of the FNs and FNs-Ca(II) complexes had a redshift. This was probably due to the different surface emission trap induced by the various functional groups present on the FNs [24]. In addition, the UV-Vis spectra showed a shoulder absorption peak in the region of 270-300 $\mathrm{nm}$ for both FNs and FNs-Ca(II), which was caused by the $\pi \rightarrow \pi^{*}$ electron transition [25]. The absorption peak of FNs-Ca(II) increased from 273 to $276 \mathrm{~nm}$ due to the electron transfer transition from chelated FNs to calcium ions in the ultraviolet region [26]. Moreover, the fluorescence lifetimes $(\tau)$ of the FNs and FNs-Ca(II) were 7.36 and 6.93 ns (Figure 2c,d), respectively. This result was similar to that reported in the study of zinc nanocarriers from beef broth [23]. All the results indicated that the nanocarriers from beef FNs had unique fluorescence, which could be used in trace analysis in organisms. 
a
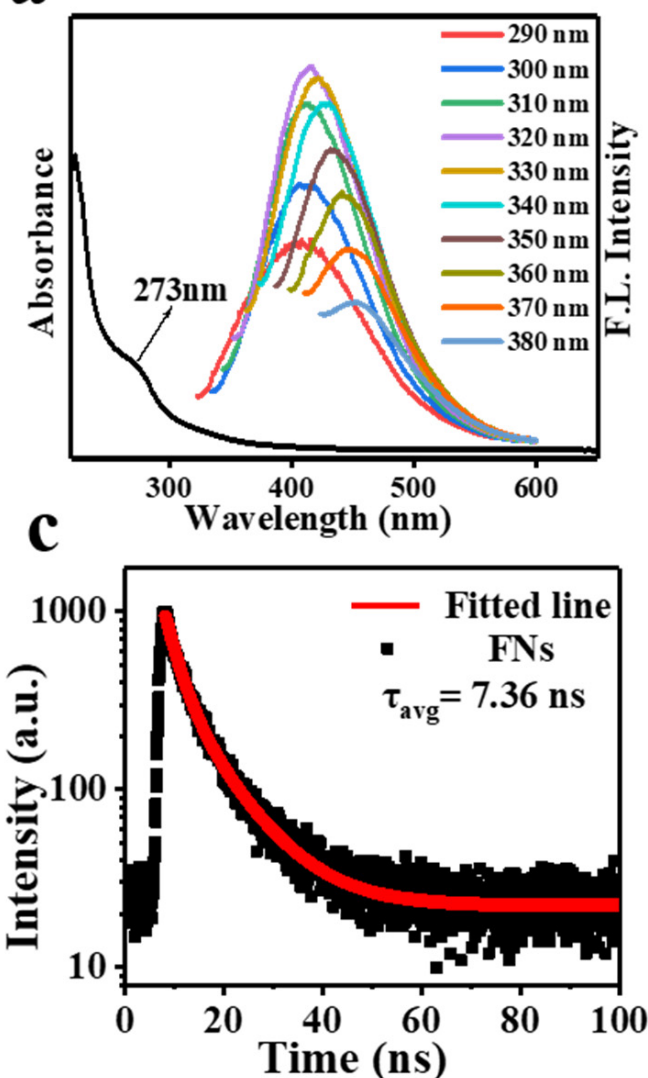

b
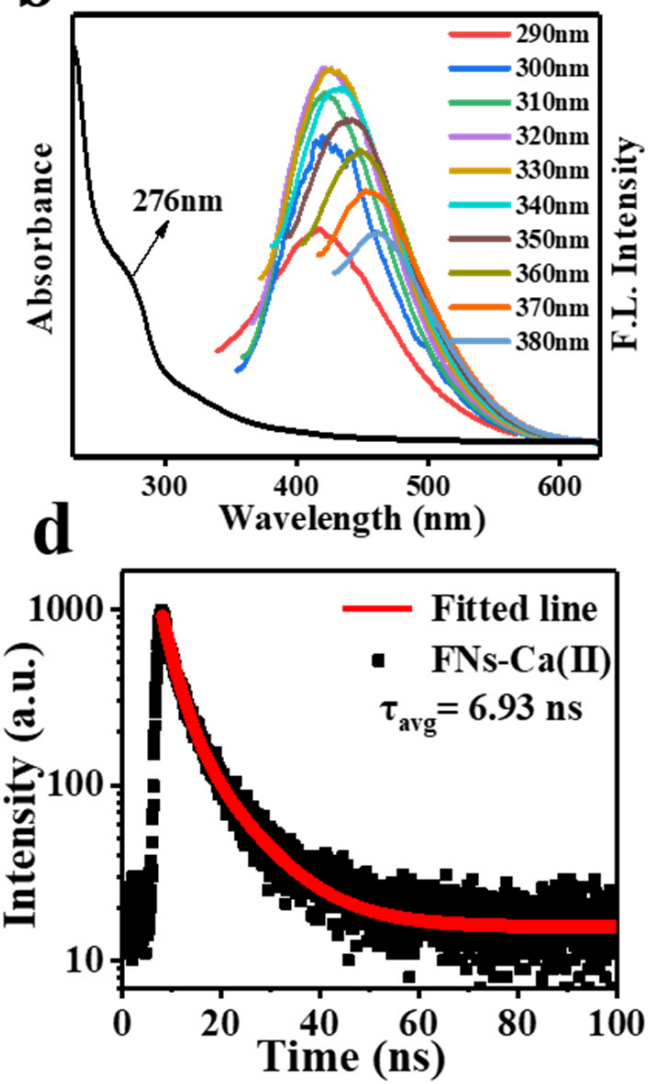

Figure 2. Fluorescence emission spectra and UV-Vis absorption spectra of FNs (a) and FNs-Ca(II) (b). Time-resolved fluorescence decay curve of FNs (c) and FNs-Ca(II) (d).

\subsection{XRD and FT-IR Analysis}

The ability and optical properties of FNs to interact with calcium ions may be due to the role of the surface functional groups of FNs. The XRD analysis of FNs (Figure 3a) showed that there was a wide diffraction peak at $2 \theta=23.38^{\circ}$, which indicated the amorphous carbon property of the FNs. Our previous work about FNs obtained from roast pork had the same results [27]. Nevertheless, the XRD analysis of FNs-Ca(II) (Figure 3b) exhibites a strong peak at $2 \theta=31.74^{\circ}$ and some sharp peaks at $2 \theta=45.53^{\circ}, 56.58^{\circ}, 66.26^{\circ}$ and $75.32^{\circ}$. Compared with that of FNs, the peaks of FNs-Ca(II) were narrow and sharper, suggesting a crystallinity nature of the FNs-Ca(II) complex. The XRD results evidently suggested that calcium ions were chelated on the FN ligands because of the presence of sharp peaks originating from the complex of FNs and calcium [28]. The FNs' FT-IR spectra and that of FNs-Ca(II) (Figure 3c) showed a clear shift of the FT-IR peaks for FNs-Ca(II), indicating the binding sites of the FNs and calcium ions. The absorption peak of both the FNs and FNs-Ca(II) at $3600-3200 \mathrm{~cm}^{-1}$ was ascribed to -OH and -NH stretching vibrations. With the coordination of calcium ions, the absorption band at $3228 \mathrm{~cm}^{-1}$ in the FNs spectrum changed to $3424 \mathrm{~cm}^{-1}$ in the FNs-Ca(II) spectrum, which indicated that an -NH group (hydrogen bond) had participated in the bonding and formed a Ca-N bond [29]. With the coordination of calcium, the vibration peak of the carboxyl group of FNs changed from $1666 \mathrm{~cm}^{-1}$ to $1633 \mathrm{~cm}^{-1}$, which suggested that the carboxyl group (COO-) was involved in the chelation with calcium. Besides, the vibration bands at $1044 \mathrm{~cm}^{-1}$ shifted to $1016 \mathrm{~cm}^{-1}$, suggesting that the calcium ions were bound to the carboxyl groups in FNs as well. Therefore, it was hypothesized that the binding sites of calcium and FNs were mainly located in the amino and carboxyl groups, which was consistent with other metalbinding FNs [15,22]. Moreover, the zeta potential can reflect the nanoparticle alteration, and the binding process may result in the change of zeta potential values. As shown in 
Figure $3 \mathrm{~d}$, the average potential of the FNs was $-0.89 \mathrm{mV}$. After chelation with $\mathrm{Ca}(\mathrm{II})$ the electronegative value increased to $2.04 \mathrm{mV}$. The charge on the surface of the FNs decreased significantly, indicating that the FNs and calcium ions formed a new FNs-Ca(II) complex.
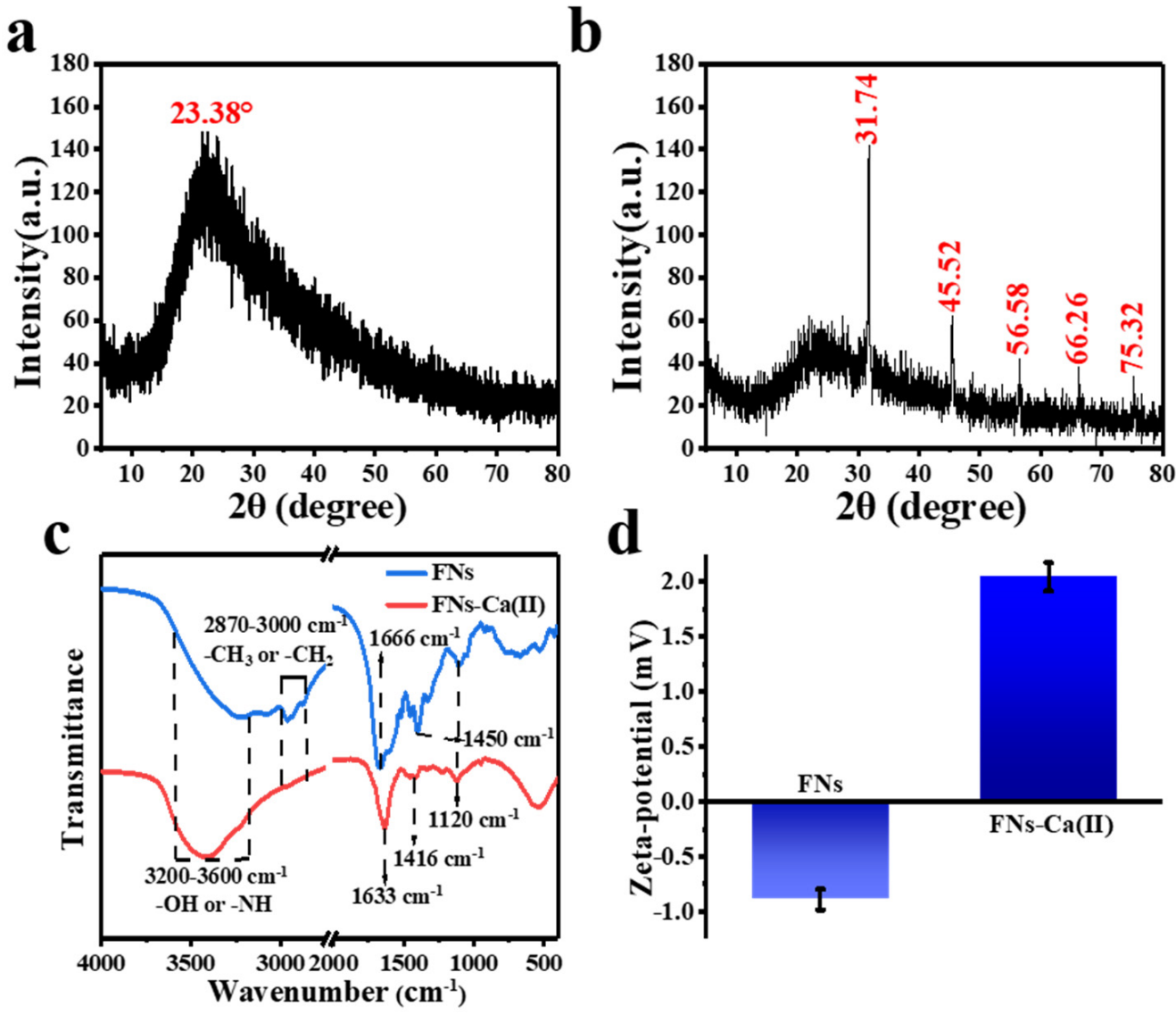

Figure 3. XRD pattern of (a) FNs and (b) FNs-Ca(II). (c) FT-IR spectra. (d) The zeta potential of FNs and FNs-Ca(II).

\subsection{XPS Analysis of FNs and FNs-Ca(II)}

The XPS analysis was performed to further investigate the structure information and surface elemental composition of the FNs and FNs-Ca(II). Signal peaks of $\mathrm{C}_{1 \mathrm{~s}}(285.8 \mathrm{eV})$, $\mathrm{N}_{1 \mathrm{~s}}(399.6 \mathrm{eV})$, and $\mathrm{O}_{1 \mathrm{~s}}(529.8 \mathrm{eV})$ for FNs were observed (Figure $\left.4 \mathrm{a}\right)$, and the FNs were composed of carbon $(66.38 \%)$, nitrogen $(12.90 \%)$, and oxygen $(20.72 \%)$. These elements were produced from the lipids, proteins, and carbohydrates in raw beef [16]. More specifically, the peaks at 284.5, 285.4, 286.3, and $287.9 \mathrm{eV}$, displayed in Figure $4 \mathrm{~b}$, confirmed the existence of $\mathrm{C}=\mathrm{C}, \mathrm{C}-\mathrm{N}, \mathrm{C}-\mathrm{O}$, and $\mathrm{C}=\mathrm{O}$ chemical bonds, respectively. Figure $4 \mathrm{c}$ shows the highresolution peaks of amide- $\mathrm{N}$ at $398.1 \mathrm{eV}$, pyridinic-N at $398.6 \mathrm{eV}$, and amino-N at $399.3 \mathrm{eV}$ in the $\mathrm{N}_{1 \mathrm{~s}}$ spectrum. The $\mathrm{O}_{1 \mathrm{~s}}$ XPS spectra of FNs (Figure 4d) was decomposed into characteristic peaks at 531.4, 532.3, and $533.2 \mathrm{eV}$, demonstrating the existence of ${ }^{*} \mathrm{O}=\mathrm{C}-\mathrm{O}$, $\mathrm{C}-\mathrm{O}$, and $\mathrm{O}=\mathrm{C}-\mathrm{O}^{*}$ bonds, respectively [30]. Notably, the XPS results were in accordance with the FT-IR results. It was confirmed that the FNs had hydroxyl, amino, and carboxyl groups on their surface. Based on this, the FNs were a good choice for calcium ion coordination. In addition, the XPS spectrum of FNs-Ca(II) (Figure 4e) showed the specific signal peak of $\mathrm{Ca}$ (II) with a binding energy of $347 \mathrm{eV}\left(\mathrm{Ca}_{2 \mathrm{p}}\right)$. The elemental ratios of $\mathrm{C}, \mathrm{N}, \mathrm{O}$, and $\mathrm{Ca}$ in $\mathrm{FNs}-\mathrm{Ca}(\mathrm{II})$ were $64.75 \%, 7.37 \%, 18.73 \%$, and $9.14 \%$, respectively. It was noteworthy that from the high-resolution $\mathrm{N}_{1 \mathrm{~s}}$ spectrum of $\mathrm{FNs}-\mathrm{Ca}(\mathrm{II})$, a new peak representative of $\mathrm{Ca}-\mathrm{N}$ at $400.8 \mathrm{eV}$ was observed (Figure $4 \mathrm{~g}$ ), indicating that calcium was successfully bonded with the beef FNs [31]. 

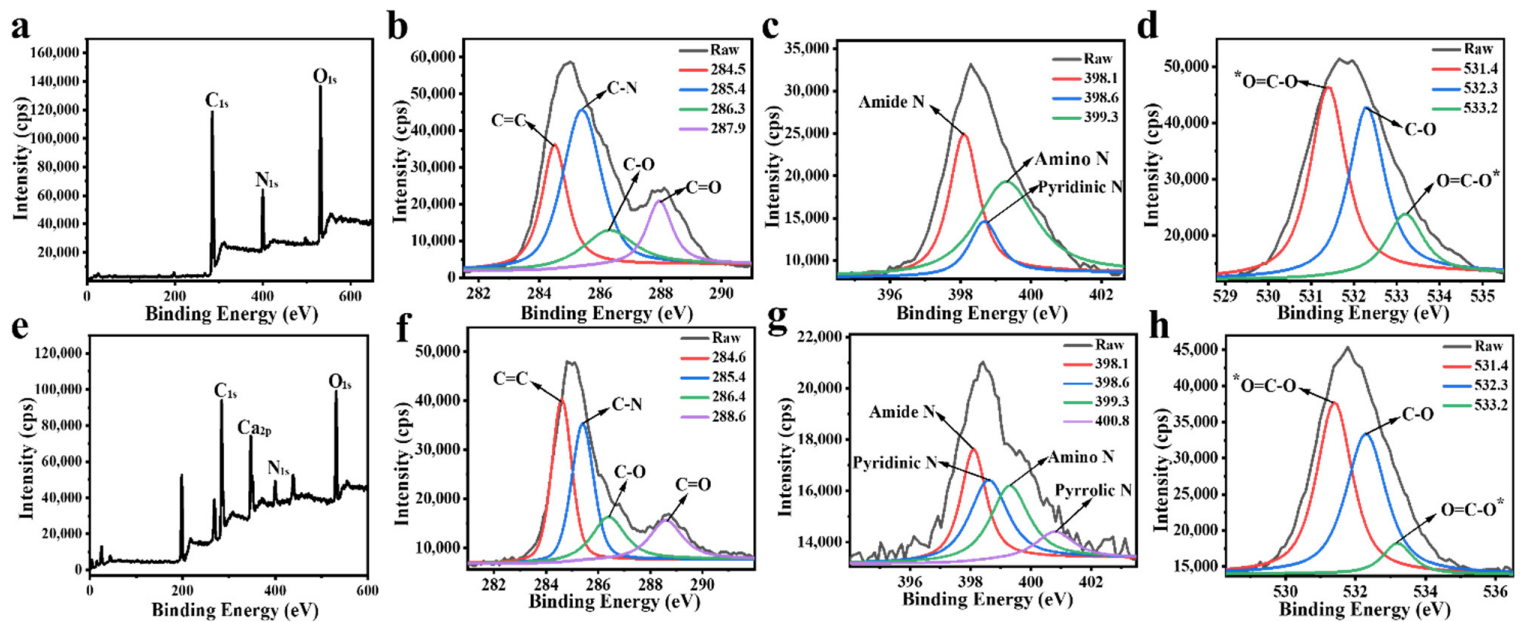

Figure 4. XPS survey of FNs (a) and FNs-Ca(II) (e). High-resolution XPS spectra of $\mathrm{C}_{1 \mathrm{~s}}(\mathbf{b}), \mathrm{N}_{1 \mathrm{~s}}$ (c), and $\mathrm{O}_{1 \mathrm{~s}}(\mathbf{d})$ for FNs, and high-resolution XPS spectra of $\mathrm{C}_{1 \mathrm{~s}}(\mathbf{f}), \mathrm{N}_{1 \mathrm{~s}}(\mathbf{g})$, and $\mathrm{O}_{1 \mathrm{~s}}(\mathbf{h})$ for FNs-Ca(II).

\subsection{EDS Analysis of FNs and FNs-Ca(II)}

Energy dispersive $X$-ray spectroscopy (EDS) has been considered as an effective technique to characterize the elements in a testing sample according to the wavelength of the characteristic X-ray emitted by the sample [32]. In order to confirm the element composition of FNs and FNs-Ca(II), an EDS element analysis was carried out for the FNs and FNs-Ca(II). Figure 5a,f show the scanning electron microscope (SEM) images of the FNs and FNs-Ca(II), respectively. The element surface scan analysis (Figure $5 \mathrm{~b}-\mathrm{d}, \mathrm{g}-\mathrm{i}$ ) showed that there were three main elements $(\mathrm{C}, \mathrm{N}$, and $\mathrm{O})$ distributed on the surfaces of the FNs and FNs-Ca(II). Significantly, 53.2\% of the Ca element appeared on the surface of FNs-Ca(II) (Figure 5j), while there was less Ca in the FNs (Figure 5e). The EDS spectrum of FNs-Ca(II) showed the specific signal peak of calcium (Ca, $3.7 \mathrm{keV})$ [33]. Combined with the results of the XPS analysis, these results show that the FNs and FNs-Ca(II) mainly contained three elements $(C, N$, and $O)$, and the calcium ions were successfully chelated with the FN carriers.

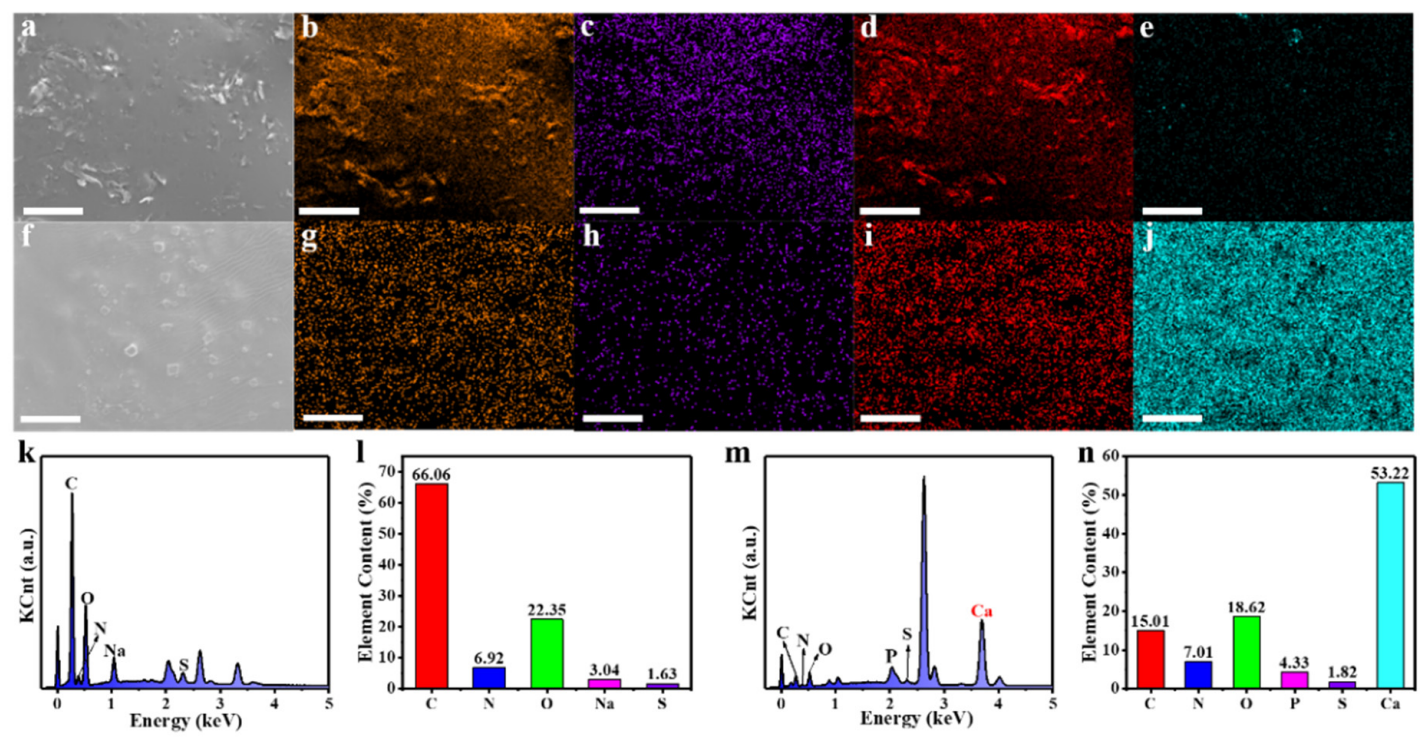

Figure 5. SEM images of FNs (a) and FNs-Ca(II) (f). Distribution diagram of $\mathrm{C}$ (b) for FNs and (g) for FNs-Ca(II); N (c) for FNs and (h) for FNs-Ca(II); O (d) for FNs and (i) for FNs-Ca(II); and Ca (e) for FNs and (j) for FNs-Ca(II). EDS spectrum of FNs (k) and FNs-Ca(II) (m), and element statistics of FNs (1) and FNs-Ca(II) (n). Scale bar is $50 \mu \mathrm{m}$. 


\section{6. ${ }^{1} \mathrm{H}$ NMR Analysis of FNs and FNs-Ca(II)}

${ }^{1} \mathrm{H}$ NMR is a powerful technique that can be used to analyse the chelation between FNs and calcium ions by measuring chemical shifts [34]. Figure 6a shows a signal at $2.5 \mathrm{ppm}$ that came from the solvent (dimethyl- $\mathrm{d}_{6}$ sulfoxide) [35]. Double peaks representing the hydrogen atom of an aromatic ring appeared at $8.181 \mathrm{ppm}$ and $8.130 \mathrm{ppm}$ in the FNs, and disappeared in $\mathrm{FNs}-\mathrm{Ca}$ (II) (Figure 6b). This may be due to the binding of calcium ions to the aromatic ring of the amino group of FNs [36]. In addition, the signals at 7.282 and $7.436 \mathrm{ppm}$ (Figure 6c) were assigned to the hydrogen signal of - $\mathrm{CH}$ in the aromatic compound [37], which shifted to 7.315 and $7.445 \mathrm{ppm}$ after binding with calcium ions. The signals at 3.385, 3.357, and $3.307 \mathrm{ppm}$ were ascribed to methylene in $-\mathrm{N}^{-\mathrm{CH}_{2}}$ (Figure 6d,e) [38-40], which changed from three peaks to one peak after binding with $\mathrm{Ca}(\mathrm{II})$. The signals at 3.142 and $3.136 \mathrm{ppm}$ were attributed to the hydrogen atom of -O-C-H [41]. The proton at $2.995 \mathrm{ppm}$, from a hydroxyl or methylene group adjacent to a nitrogen atom, disappeared in the ${ }^{1} \mathrm{H}$ NMR spectrum of FNs-Ca(II) (Figure 6f) [42]. The signals at 1.256 and $1.240 \mathrm{ppm}$ were likely due to a hydrogen in a methyl group. (Figure $6 \mathrm{~g}$ ). The two peaks disappeared after the formation of the FNs-Ca(II) complex [43]. These chemical shifts also showed that $\mathrm{Ca}$ (II) was combined with the FNs using the hydroxyl and amino groups for $\mathrm{Ca}$ (II) coordination.

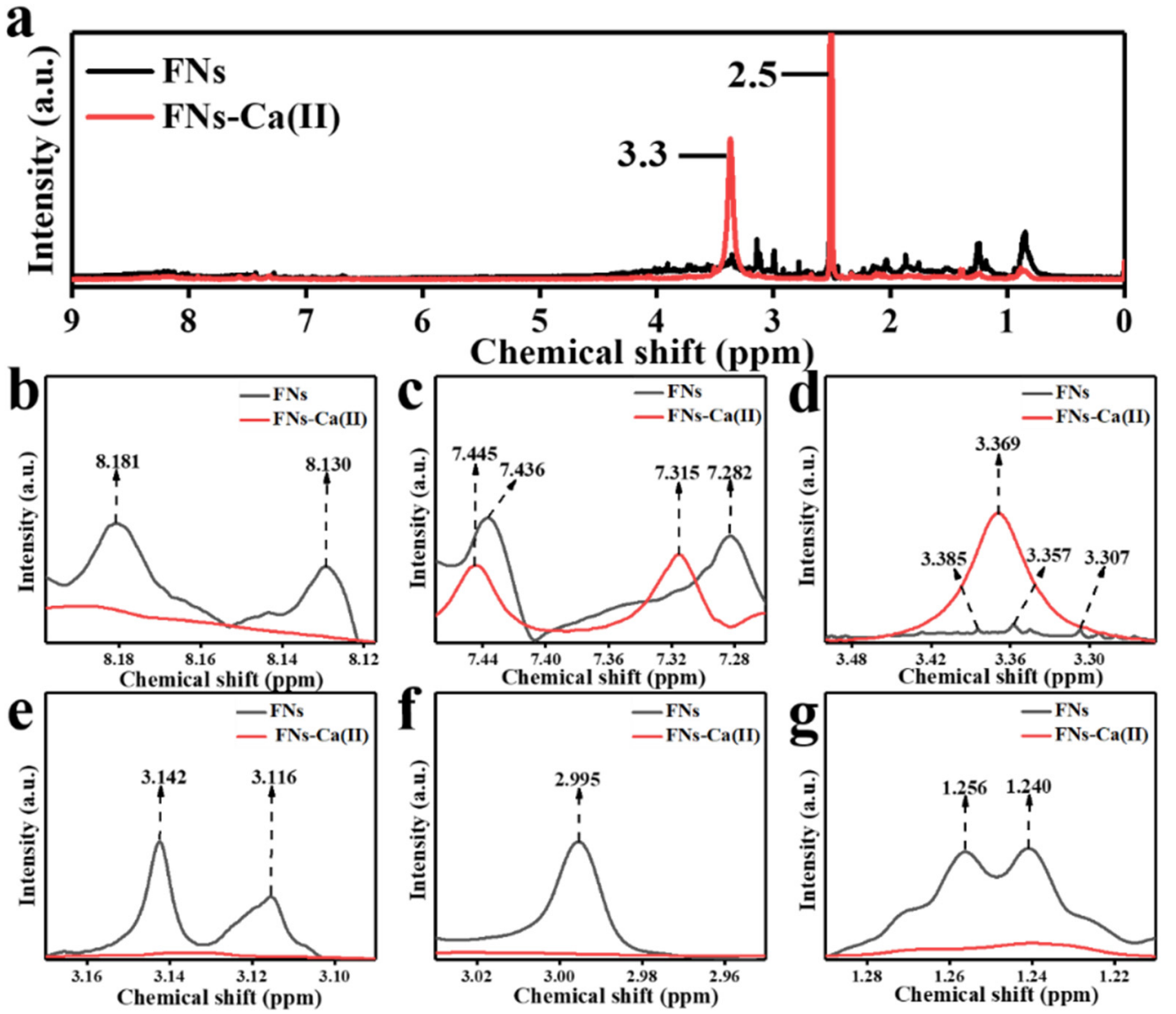

Figure 6. ${ }^{1} \mathrm{H}$ nuclear magnetic resonance (NMR) spectra of the FNs and FNs-Ca(II) (a), and enlarged ${ }^{1} \mathrm{H}$ NMR spectra (b-g) showing the specific NMR peaks of the FNs and FNs-Ca(II).

\subsection{Cellular Bio-Distribution and Cytotoxicity of FNs and FNs-Ca(II)}

Nanoparticles can cross biological barriers and deliver cargo as carriers to cells [44]. The biocompatibility of FNs-Ca(II) was studied by co-culture with Caco-2 cells. We used annexin V-FITC and PI staining methods to evaluate the cytotoxicity of FNs-Ca(II) (Figure 7). The cell viability was $99.50 \%$ in the blank control group, which decreased to $70.7 \%$ for the FNs and $69.9 \%$ for FNs-Ca(II). The apoptosis rates of FNs-Ca(II) and the FNs were $20.06 \%$ 
and $24.36 \%$, respectively, when they were both at $1 \mathrm{mg} \mathrm{mL}^{-1}$. In addition, the necrosis rate of $\mathrm{FNs}-\mathrm{Ca}$ (II) was $10.30 \%$, compared with a rate of $1.93 \%$ for the FNs. It is well all known that almost all cell responses, from contraction and exocytosis to gene expression and cell death, are controlled by changes in $\mathrm{Ca}$ (II) concentration in the cytoplasm [45]. After entering the Caco-2 cells, a great deal of calcium ions were released from FNs-Ca(II), which increased the concentration of calcium ions in the cytoplasm and eventually resulted in an increase in cell necrosis rate. In particular, adding free calcium ions resulted in the highest necrosis percentage of $11.9 \%$ under the same concentration treatment. Therefore, the FNs can not only be used as carriers for calcium ions, but can also be used to improve the biocompatibility of $\mathrm{Ca}(\mathrm{II})$. The influence of $\mathrm{FNs}-\mathrm{Ca}(\mathrm{II})$ on the percentage of living cells was also evaluated using an MTT assay (Figure 7f). The cytotoxicity assay of the Caco-2 cells showed that the cell viability decreased in all samples when the concentration increased from 0 to $3.0 \mathrm{mg} \mathrm{mL}^{-1}$. The viability of the cells treated with FNs was more than $75 \%$, while viability was only $65 \%$ after treatment with $\mathrm{FNs}-\mathrm{Ca}$ (II) and $60 \%$ after $\mathrm{CaCl}_{2}$ treatment. This biocompatibility of $\mathrm{FNs}-\mathrm{Ca}(\mathrm{II})$ was improved in contrast to that of $\mathrm{CaCl}_{2}$. Compared with the previous nanocarriers that could bind ferrous ions and zinc ions in roast beef patties and beef broth, respectively, we found that the FNs and FNs-Ca(II) had the characteristic of low toxicity $[15,26]$. These results showed that the FNs-Ca(II) complex has lower cytotoxicity and thus a great potential for application as a carrier for calcium supplements.
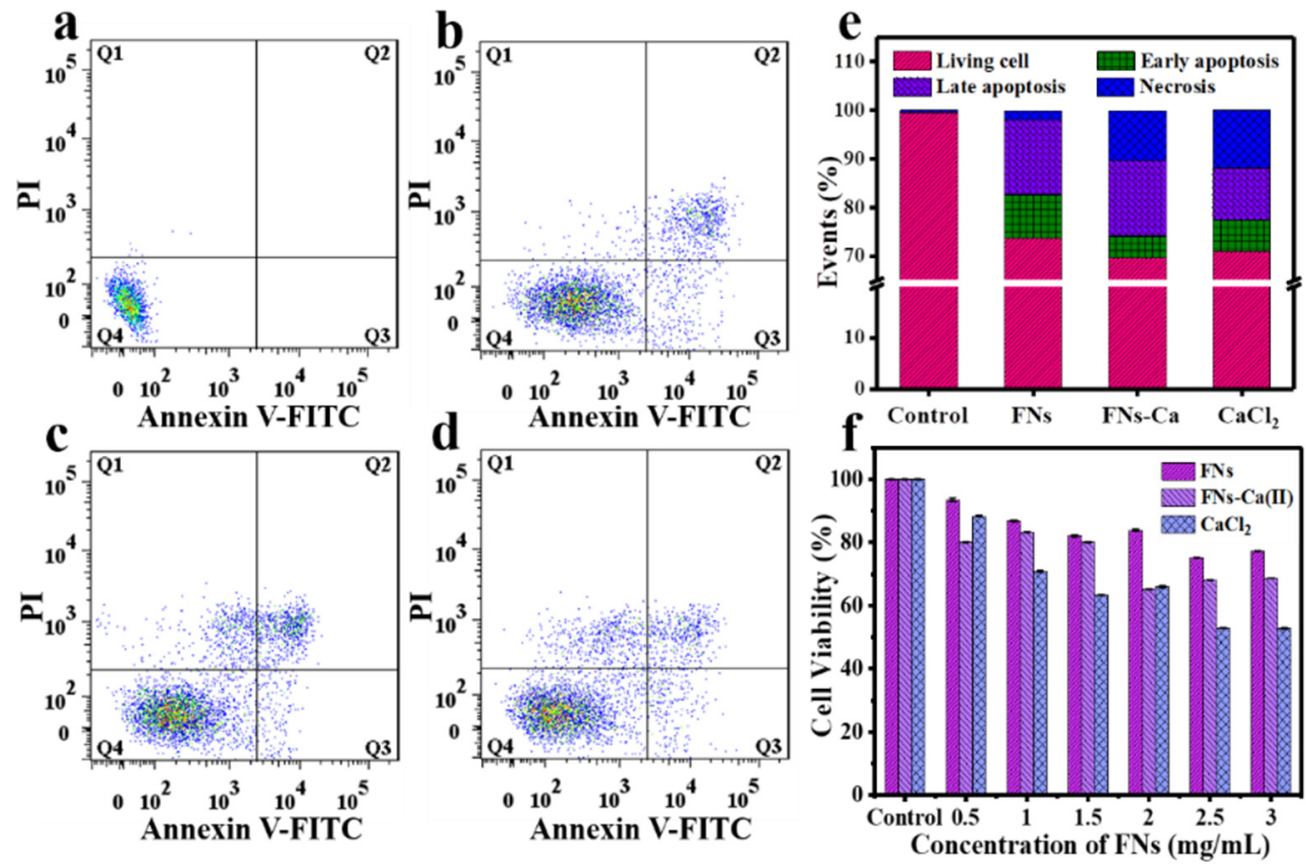

Figure 7. Flow cytometry characterization of Caco-2 cells in control (a), $1 \mathrm{mg} \mathrm{mL}^{-1}$ of $\mathrm{FNs}(\mathbf{b})$, $1 \mathrm{mg} \mathrm{mL}^{-1}$ of FNs-Ca(II) (c), and $1 \mathrm{mg} \mathrm{mL}^{-1}$ of $\mathrm{CaCl}_{2}$ (d). (e) Relative apoptosis of cells treated with FNs, FNs-Ca(II), and $\mathrm{CaCl}_{2}$. (f) Cytotoxicity of Caco-2 cells treated with FNs, $\mathrm{FN}-\mathrm{Ca}(\mathrm{II})$, and $\mathrm{CaCl}_{2}$.

The unique blue fluorescence properties of the FNs and FNs-Ca(II) were helpful to monitor their distribution in cells. Figure 8 shows the bright-field images and fluorescence images under the irradiation of a $405 \mathrm{~nm}$ laser after a $24 \mathrm{~h}$ incubation with the FNs and FNs-Ca(II). Blue fluorescence was observed after treatment with FNs and FNs-Ca(II) under an excitation wavelength of $405 \mathrm{~nm}$. It can be seen that most of the FNs and FNs-Ca(II) were distributed in the cytoplasm of the cells instead of in the nucleus (Figure 8e,h). The FNs and FNs-Ca(II) distributed in the Caco-2 cells can be found in the overlay images. The results revealed that the $\mathrm{FNs}-\mathrm{Ca}$ (II) complex was internalized into the cytoplasm of the Caco- 2 cells, which was consistent with the previous observations of nanocarriers in roast beef patties and beef broth $[15,26]$. 


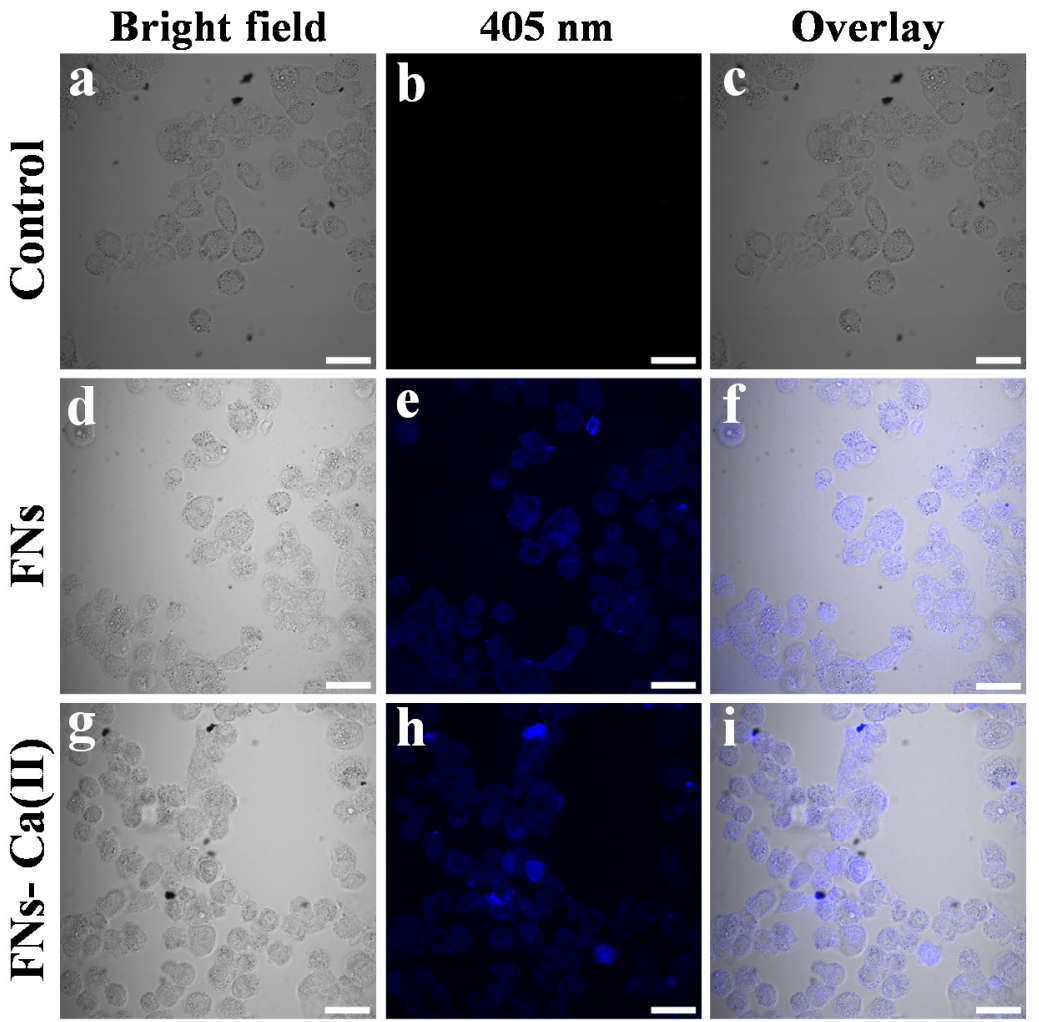

Figure 8. Confocal laser fluorescence images of Caco-2 cells treated with FNs and FNs-Ca(II) with a $408 \mathrm{~nm}$ laser. Bright-field images of Caco-2 cells (a,d,g), fluorescence images of Caco-2 cells (b,e,h), and overlay images of Caco-2 cells $(\mathbf{c}, \mathbf{f}, \mathbf{i})$. Scale bar representing $30 \mu \mathrm{m}$.

\section{Conclusions}

In conclusion, FNs from beef were prepared by green synthesis using the hydrothermal method. The FNs had a small size, blue fluorescence, plenty of functional groups, and good biocompatibility. The functional groups on the surface of the FNs made significant contributions to the chelation of $\mathrm{Ca}(\mathrm{II})$, and the amino nitrogen atom and carboxyl oxygen atom were the main binding sites. Our data suggest that the FNs produced from beef might be used for loading calcium in the development of a calcium supplement. The FNs are derived from the nutritional ingredients of beef, which may be desirable for a healthpromoting calcium supplement. Meanwhile, $\mathrm{FNs}-\mathrm{Ca}$ (II) has the potential to be developed into a calcium nanocarrier, and is expected to become a new calcium supplement. The results of this study also provided a new strategy for developing food-borne nanocarriers for other microelement supplements.

Supplementary Materials: The following are available online at https:/ /www.mdpi.com/article/10 .3390 / foods11030308/s1, Figure S1: (a) Determination of calcium binding capacity and (b) calcium standard curve.

Author Contributions: Conceptualization, M.T. and N.W.; methodology, N.W.; software, Y.C.; formal analysis, N.W.; data curation, Y.C.; writing-original draft preparation, N.W.; writing-review and editing, N.W., Y.C., Y.S., D.Y. and M.T.; project administration, M.T. All authors have read and agreed to the published version of the manuscript.

Funding: This work was funded by the National Science Fund for Distinguished Young Scholars of China (31925031).

Data Availability Statement: The datasets generated for this study are available on request to the corresponding author.

Conflicts of Interest: The authors declare no conflict of interest. 


\section{References}

1. Mertz, W. The essential trace elements. Science 1981, 213, 1332-1338. [CrossRef]

2. Xie, Y.; Yi, G.; Zhang, A. Effects of calcium in physiology and metabolism of fruit crops. J. Fruit Sci. 2003, 20, 369-373.

3. Marie, P.J.; Pettifor, J.M.; Ross, F.P.; Glorieux, F.H. Histological osteomalacia due to dietary calcium deficiency in children. N. Engl. J. Med. 1982, 307, 584-588. [CrossRef] [PubMed]

4. Ally, M.; Tang, J.Y.; Joselyn, L.; Maria, A.R.; Melika, R.; Chanana, A.M.; Epstein, E.H. Calcium channel blockade and vismodegibinduced muscle cramps. Jama Dermatol. 2015, 151, 1132-1134. [CrossRef] [PubMed]

5. Fievet, P.; Fournier, A.; De, B.A.; El, E.N.; Gregoire, I.; Westeel, P.F.; Renaud, H.; Makdassi, R. Atrial natriuretic factor in pregnancy-induced hypertension and preeclampsia: Increased plasma concentrations possibly explaining these hypovolemic states with paradoxical hyporeninism. Am. J. Hypertens. 1988, 1, 16-21. [CrossRef] [PubMed]

6. Lipschitz, A.D. Nutrition and health in the elderly. Curr. Opin. Gastroen. 1991, 7, 277-283. [CrossRef]

7. Namkung, M.H.; Appleyard, R.; Jansen, J.; Lin, J.H.; Diamond, T. Osteoporosis influences the early period of fracture healing in a rat osteoporotic model. Bone 2001, 28, 80-86. [CrossRef]

8. Mishra, B.; Sharma, G.; Shukla, D. Investigation of organoleptic characteristics in the development of soft chews of calcium carbonate as mineral supplement. J. Pharm. Soc. Jap. 2009, 129, 1537-1544. [CrossRef]

9. Behar, J.; Hitchings, M.; Smyth, R.D. Calcium stimulation of gastrin and gastric acid secretion: Effect of small doses of calcium carbonate. Gut 1977, 18, 442-448. [CrossRef]

10. Heller, J.H. The role of calcium in the prevention of kidney stones. J. Am. Coll. Nutr. 1999, 18, 373S-378S. [CrossRef]

11. Atsutane, O.; Masako, O.; Seigo, B.; Takashi, A.; Takashi, S.; El, S. Calcium and magnesium absorption from the colon and rectum are increased in rats fed fructooligosaccharides. J. Nutr. 1995, 125, 2417-2424.

12. Mellander, O.; Isaksson, B. The physiological importance of the casein phosphopeptide calcium salts. I. intravenous and peroral calcium cosage in animal experiments. Acta. Soc. Bot. Pol. 1950, 55, 239-246.

13. Wu, W.; Li, B.; Hou, H.; Zhang, H.; Zhao, X. Isolation and identification of calcium-chelating peptides from pacific cod skin gelatin and their binding properties with calcium. Food Funct. 2017, 8, 4441-4448. [CrossRef] [PubMed]

14. Cui, P.; Songyi, L.; Ziqi, J.; Zhu, B.W.; Liang, S.; Na, S. In vitro digestion profile and calcium absorption studies of sea cucumber ovum derived heptapeptide-calcium complex. Food Funct. 2018, 9, 4582-4592. [CrossRef] [PubMed]

15. Wang, N.Y.; Wu, Y.Y.; Zhao, X.; Lai, B.; Sun, N.; Tan, M.Q. Food-borne nanocarriers from roast beef patties for iron delivery. Food Funct. 2019, 10, 6711-6719. [CrossRef] [PubMed]

16. Li, Y.; Bi, J.; Liu, S.; Wang, H.; Tan, M. Presence and formation of fluorescence carbon dots in grilled hamburger. Food Funct. 2017, 8, 2558-2565. [CrossRef]

17. Bi, J.; Li, Y.; Wang, H.; Song, Y.; Cong, S.; Yu, C.; Zhu, B.W.; Tan, M. Presence and formation mechanism of foodborne carbonaceous nanostructures from roasted pike eel (Muraenesox cinereus). J. Agric. Food Chem. 2018, 66, 2862-2869. [CrossRef]

18. Cong, S.; Wang, N.Y.; Wang, K.; Wu, Y.; Li, D.; Song, Y.; Prakash, S.; Tan, M.Q. Fluorescent nanoparticles in the popular pizza: Properties, biodistribution and cytotoxicity. Food Funct. 2019, 10, 2408-2416. [CrossRef]

19. Alam, A.; Park, B.; Ghouri, Z.K.; Kim, H.Y. Synthesis of carbon quantum dots from cabbage with down- and up-conversion photoluminescence properties: Excellent imaging agent for biomedical applications. Green Chem. 2015, 17, 3791-3797. [CrossRef]

20. Wang, L.; Zhou, H.S. Green synthesis of luminescent nitrogen-doped carbon dots from milk and its imaging application. Anal. Chem. 2014, 86, 8902-8905. [CrossRef]

21. Song, Y.K.; Liu, K.J.; Su, W.T.; Hou, S.; Che, T.T.; Tan, M.Q. Construction and evaluation of an iron delivery system by ultra-small nanoparticles from roast sturgeon (Acipenser schrenckiid). Food Funct. 2021, 12, 1147-1155. [CrossRef] [PubMed]

22. Geng, J.X.; Song, X.Y.; Zhang, X.D.; Tie, S.S.; Cao, L.; Tan, M.Q. Hydrophilic food-borne nanoparticles from beef broth as novel nanocarriers for zinc. J. Agric. Food Chem. 2019, 67, 6995-7004. [CrossRef] [PubMed]

23. Wang, H.T.; Xie, Y.S.; Na, X.K.; Bi, J.R.; Liu, S. Fluorescent carbon dots in baked lamb: Formation, cytotoxicity and scavenging capability to free radicals. Food Chem. 2019, 286, 405-412. [CrossRef]

24. Van, D.B.; Nie, H.; Ju, B.; Marino, E.; Paulusse, J.M.J.; Schall, P.; Li, M.; Dohnalová, K. Excitation-dependent photoluminescence from single-carbon dots. Small 2017, 13, 1702098.

25. Wu, H.; Yang, Z.; Chen, C.; Zhang, J.; Zhang, H.; Peng, H.; Wang, F. Synthesis, crystal structures, antioxidant activities, and DNA-binding studies of two silver (I) complexes with 1,3-bis(1-ethylbenzimidazol-2-yl)-2-thiapropane, and $\alpha, \beta$-unsaturated carboxylates. J. Coord. Chem. 2016, 69, 1076-1087. [CrossRef]

26. Scandola, F.; Indelli, M.T.; Chiorboli, C.; Bignozzi, C.A. Photoinduced electron transfer II. Cheminform 1990, $22,73-149$.

27. Zhao, C.; Jiao, Y.; Hu, F.; Yang, Y. Green synthesis of carbon dots from pork and application as nanosensors for uric acid detection. Spectrochim. Acta. A Mol. Biomol. Spectrosc. 2018, 190, 360-367. [CrossRef]

28. Wang, F.; Xu, Z.; Zhang, Y.; Li, J.; Nian, S.; Zhou, N. Green synthesis and bioactivity of vaterite-doped beta-dicalcium silicate bone cement. Ceram. Int. 2016, 42, 1856-1861. [CrossRef]

29. Peng, Z.; Hou, H.; Zhang, K.; Li, B. Effect of calcium-binding peptide from pacific cod (Gadus macrocephalus) bone on calcium bioavailability in rats. Food Chem. 2017, 221, 373-378. [CrossRef]

30. Zhao, X.; Shan, S.; Li, J.; Cao, L.; Tan, M. Assessment of potential toxicity of foodborne fluorescent nanoparticles from roasted pork. Nanotoxicology 2019, 13, 1310-1323. [CrossRef] 
31. Yang, Y.; Faheem, M.; Wang, L.; Meng, Q.; Sha, H.; Yang, N.; Yuan, Y.; Zhu, G. Surface pore engineering of covalent organic frameworks for ammonia capture through synergistic multivariate and open metal site approaches. ACS Cent. Sci. 2018, 4, 748-754. [CrossRef] [PubMed]

32. Manuel, S.; Simone, B.; Harpreet, K.L.; Rita, B.; Elena, B. Energy dispersive X-ray (EDX) microanalysis: A powerful tool in biomedical research and diagnosis. Eur. J. Histochem. EJH 2018, 62, 89-99.

33. Colboc, H.; Moguelet, P.; Bazin, D.; Bachmeyer, C.; Frochot, V.W. Physicochemical characterization of inorganic deposits associated with granulomas in cutaneous sarcoidosis. J. Eur. Acad. Dermatol. 2019, 33, 198-203. [CrossRef] [PubMed]

34. Hinton, J.F.; Amis, E.S. Nuclear magnetic resonance studies of ions in pure and mixed solvents. Chem. Rev. 1967, 67, 367-425. [CrossRef]

35. Bergana, M.M.; Adams, K.M.; Harnly, J.; Moore, J.C.; Xie, Z. Non-targeted detection of milk powder adulteration by ${ }^{1} \mathrm{H}$ NMR spectroscopy and conformity index analysis. J. Food Compos. Anal. 2019, 78, 49-58. [CrossRef]

36. Corcilius, L.; Liu, D.Y.; Ochoa, J.L.; Linington, R.G.; Payne, R.J. Synthesis and evaluation of analogues of the glycinocin family of calcium-dependent antibiotics. Org. Biomol. Chem. 2018, 16, 5310-5320. [CrossRef]

37. Do, H.H.; Hauptmann, R.; Villinger, A.; Surkus, A.E.; Lochbrunner, S.; Ehlers, P.; Langer, P. Palladium-catalyzed synthesis and fluorescence study of 2,3-diaryl-5-ethynylbenzo [e] indoles. Tetrahedron 2017, 73, 3407-3414. [CrossRef]

38. Gottlieb, H.E.; Kotlyar, V.; Nudelman, A. NMR chemical shifts of common laboratory solvents as trace impurities. J. Org. Chem. 1997, 62, 7512-7515. [CrossRef]

39. Francisco, H.U.; Nuria, A.I.C.; Miguel, N.M.C.; Antonio, L.P.C.; René, F. Ni(II) and Cu(II) complexes with the dianionic N,N,Otridentate schiff base 6-amino-5-formyl-1,3-dimethyluracil-benzoylhydrazone: Crystal structure of the monodimensionally hydrogen-bonded aqua-(6-amino-1,3-dimethyl-uracilato-benzoylhydrazone(2-)-N6,N51,O5. Polyhedron 2000, 19, $689-693$.

40. Trivedi, A.R.; Dodiya, D.K.; Ravat, N.R.; Shah, V.H. Synthesis and biological evaluation of some new pyrimidines via a novel chalcone series. Arkivoc 2008, 11, 131-141. [CrossRef]

41. Steven, A.R.; Gordon, L. Downfield displacement of the NMR signal of water in deuterated dimethylsulfoxide by the addition of deuterated trifluoroacetic acid. Tetrahedron Lett. 2000, 41, 3225-3227.

42. Grigoras, M.; Sava, M.; Colotin, G.; Simionescu, C.I. Synthesis and thermal behavior of some anthracene-based copolymers obtained by diels-alder cycloaddition reactions. J. Appl. Polym. Sci. 2008, 107, 846-853. [CrossRef]

43. Khalturina, V.; Shklyaev, Y.V.; Aliev, Z.; Maslivets, A. Five-membered 2, 3-dioxoheterocycles: LXIV. reactions of 1-methyl-3, 4-dihydroisoquinolines with 5-arylfuran-2, 3-diones and (Z)-alkyl 4-aryl-2-hydroxy-4-oxobut-2-enoates. crystal and molecular structure of (2Z,5Z)-3-hydroxy-5-\{8,8-dimethyl-2,3,8,9-tetrahydro [1,4] dioxino [2,3-g] isoquinolin-6 (7H)-ylidene\}-1-phenylpent-2ene-1, 4-dione. Russ. J. Org. Chem. 2009, 45, 728-734.

44. Ferrari, M. Frontiers in cancer nanomedicine: Directing mass transport through biological barriers. Trends Biotechnol. 2010, 28, 181-188. [CrossRef]

45. Verkhratsky, A.; Toescu, E. Endoplasmic reticulum $\mathrm{Ca}^{2+}$ homeostasis and neuronal death. J. Cell. Mol. Med. $2003,7,351-361$. [CrossRef] [PubMed] 